\title{
ONE-POT SYNTHESIS OF ISOBENZOFURAN-1(3H)-ONES USING SULFURIC ACID IMMOBILIZED ON SILICA UNDER SOLVENT-FREE CONDITIONS AND SURVEY OF THIRD-ORDER NONLINEAR OPTICAL PROPERTIES
}

\author{
BEHROOZ MALEKI ${ }^{*}$, EHSAN KOUSHKI ${ }^{2}$ MEHDI BAGHAYERI ${ }^{1}$, SAMANEH SEDIGH ASHRAFI \\ ${ }^{1}$ Department of Chemistry, Hakim Sabzevari University, Sabzevar, 96179-76487, Iran \\ ${ }^{2}$ Department of Physics, Hakim Sabzevari University, Sabzevar, 96179-76487, Iran
}

\begin{abstract}
Solvent-free synthesis of isobenzofuran-1(3H)-ones have been described via reaction of phthalaldehydic acid (2-carboxybenzaldehyde) with methylaryl or cyclic ketones using sulfuric acid immobilized on silica $\left(\mathrm{H}_{2} \mathrm{SO}_{4}-\mathrm{SiO}_{2}\right)$ in excellent yields $(70-88 \%)$. The catalyst can be recovered by simple filtration and reused. Also, some of these compounds has been studied the third-order nonlinear optical properties by laser Gaussian z-scan techniques.
\end{abstract}

\section{INTRODUCTION}

Isobenzofuran-1 $(3 H)$-ones and their derivatives are very important biological compounds that occur widely in natural products. Typical examples are are fuscinarin $(\mathbf{1})^{1}$, typhaphthalide $(\mathbf{2})^{2}$, catalpalactone $(3)^{3}$, alcyopterosin E $(\mathbf{4})^{4},(+)$-spirolaxine $(5)^{5}$, vermistatin $(\mathbf{6})^{6}$, rubiginone-H (7) ${ }^{7},(-)$-hydrastine $(\mathbf{8})^{8}$, isopestacin $(\mathbf{9})^{9}$, and cryphonectricacid $(\mathbf{1 0})^{10}$.<smiles>CC1OC(=O)c2c3c(c(O)c(O)c21)OC(C)(C)CC3</smiles><smiles>O=C1OC(Cc2ccccc2)c2cccc(O)c21</smiles>

Fuscinarin (1)

Typhaphthalide (2)<smiles>CC1(C)CC=C(C2OC(=O)c3ccccc32)C(=O)O1</smiles>

Catalpalactone (3)

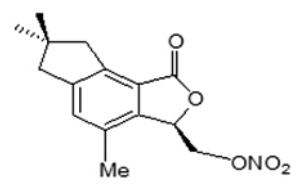

Alcyopterosin E (4)<smiles>C/C=C/c1cc(=O)c(C(=O)CC2OC(=O)c3cc(OC)cc(OC)c32)co1</smiles><smiles>COc1cccc2c1C(c1ccc3c(c1O)C(=O)C(O)C(C)C3OC(C)=O)OC2=O</smiles>

(+)-Spirolaxine (5)

Vermistatin (6)

Rubiginone $\mathrm{H}(\mathbf{7})$

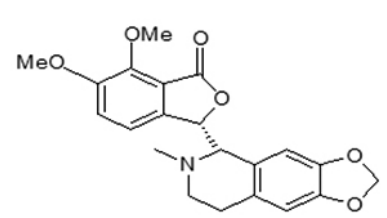

(-)-Hydrastine (8)

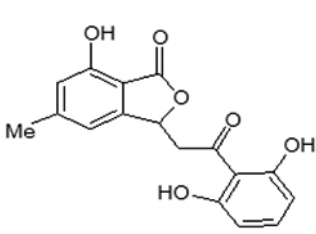

Isopestacin (9)<smiles>O=C(O)c1cc(O)c(C(=O)CC2OC(=O)c3c(O)cc(O)cc32)c(O)c1</smiles>

Cryphonectric Acid (10)

Figure 1.

Some members of this family have displayed interesting physiological activities and found attractive applications in medicinal chemistry, being used as anti-bacterial, anti-convulsant, anti-HIV, anti-asthmatic, anti-tumor, anti-plateletactivities, anesthesiaprolongation, and $\mathrm{PGF}_{2}$ ainhibitory properties 11,12. 3-Alkylidene phthalide derivatives are known for their anti-spasmodic, herbicidal, and insecticidal properties and 3-styryl phthalides are used as color formers for heat and pressure sensitive recording materials ${ }^{13}$. Also, isobenzofuran-1(3H)-ones are valuable intermediates in the synthesis of a polycyclic compounds ${ }^{14}$. Because of importance of these kinds of compounds, development of a general and efficient synthetic strategy to synthesize those compounds is still desired.

Due to the potential of phthalides, a number of methods have been developed for their synthesis. These methods include cyclization reractions catalyzed by strong bases such as DBU ${ }^{15,16}, \mathrm{NaOH}^{17}, \mathrm{KOH}{ }^{18}, \mathrm{NaOCH}_{3}{ }^{19}$, $\mathrm{NaOC}_{2} \mathrm{H}_{5}{ }^{20},\left(\mathrm{C}_{2} \mathrm{H}_{5}\right)_{2} \mathrm{NH}^{21}$. Strong acides such as $\mathrm{CF}_{3} \mathrm{COOH}{ }^{22}, \mathrm{CF}_{3} \mathrm{SO}_{3} \mathrm{H}^{23}$, montmorillonite $\mathrm{K}-10^{24}, \mathrm{Ac}_{2} \mathrm{O}^{25}, \mathrm{ZrOCl}_{2} \cdot 8 \mathrm{H}_{2} \mathrm{O}^{26}$, are also used in the synthesis of 3 -alkyl phthalides. Some of the above mentioned methods including, the use of strong corrosive and harmful acides or bases, low yields, long reactions times and tedious work up.

In recent years, the use of solid acids as heterogeneous catalysts has received tremendous interest in different areas of organic synthesis. Heterogeneous solid acids have advantageous higher than conventional homogeneous acid catalysts. As Heterogeneous solid acids can be easily recovered from the reaction mixture by simple filtration, they can be reused after activation or without activation. The main drawback of the bulk catalyst is its low specific surface area. Therefore, it is important to increase the surface area or even better to increase the number of accessible active sites of the catalyst. In order to reach to this objective, the catalyst is usually deposited on the surface of a solid support with high surface area and suitable mechanical strength which is able not only to disperse the catalyst. But it can increase its thermal stability and 
the catalyst life. In supported catalysts, the catalytic behavior of the catalyst is strongly dependent on support properties. Among the various supported catalysts, particularly, alumina and silica supported reagents have advantages of low cost, ease of preparation, and catalyst recycling ${ }^{27-35}$.

Our new approach is based on the use of a solid acid $\left(\mathrm{H}_{2} \mathrm{SO}_{4} \cdot \mathrm{SiO}_{2}\right)$ catalyzed cyclization of phthaldehydic acid with aryl ketones and 1,3-dicarbonyl compounds that are all commercially available. Finally, the presence of multiple $\pi$ electrons with different structures and conjugation lengths impelled us to study optical properties associated with these electrons called optical nonlinearity. The results were interesting from view point of optical application.

\section{RESULTS AND DISCUSSION}

In continuation of our research to develop new and eco-friendly synthetic methodologies ${ }^{36-46}$, we herein present efficient and environmentally benign protocols for the synthesis of isobenzofuran-1(3H)-one derivatives by condensation of phthalaldehydic acid (2-carboxy benzaldehyde) with aryl ketones or 1,3-dicarbonyl compounds catalyzed by $\mathrm{H}_{2} \mathrm{SO}_{4}-\mathrm{SiO}_{2}$ under solventfree conditions at $120^{\circ} \mathrm{C}$ (Scheme 1).

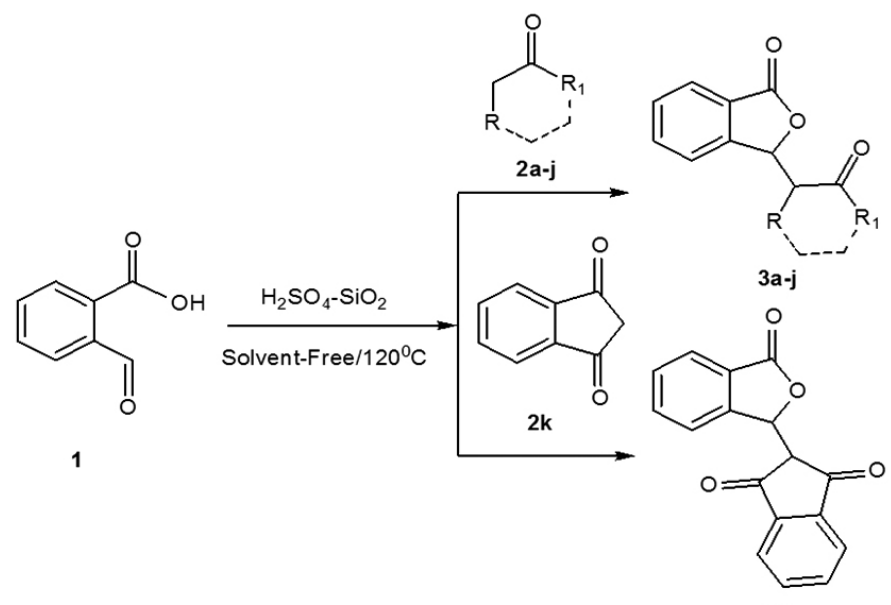

3k

Scheme 1. Synthesis of isobenzofuran-1(3H)-one derivatives by condensation of phthalaldehydic acid (2-carboxy benzaldehyde) with aryl ketones or 1,3-dicarbonyl compounds catalyzed by $\mathrm{H}_{2} \mathrm{SO}_{4}-\mathrm{SiO}_{2}$

The Effect of Temperature and Amount Catalyst on the Rate and Yeild of the Reaction Phthalaldehydic acid with Acetophenone

To choose optimum conditions, we initially investigated the reaction of phthalaldehydic acid $(1 \mathrm{mmol})$ with acetophenone $(1.2 \mathrm{mmol})$ in the presence of acid catalysts such as $\mathrm{AcOH}, \mathrm{H}_{2} \mathrm{SO}_{4}, \mathrm{NH}_{4} \mathrm{H}_{2} \mathrm{PO}_{4}-\mathrm{SiO}_{2} \mathrm{AlCl}_{3} .6 \mathrm{H}_{2} \mathrm{O}, \mathrm{P}_{2} \mathrm{O}_{5}-$ $\mathrm{SiO}_{2}$, Poly [AMPS-co-AA], and $\mathrm{H}_{2} \mathrm{SO}_{4}-\mathrm{SiO}_{2}$ in different media (Table 1, entry $1-8$ ). Best result was obtained in the presence of catalytic amount of $\mathrm{H}_{2} \mathrm{SO}_{4}$ $\mathrm{SiO}_{2}$ (entry 7) The use of $0.1 \mathrm{ml}$ of $\mathrm{H}_{2} \mathrm{SO}_{4}(18 \mathrm{M})$ in reaction condition, the yield unexpectedly decreased to trace (entry 2 ). A possible explanation for the trace product yield is that the starting material or the product may be destroyed during the reaction when $0.1 \mathrm{ml}$ of $\mathrm{H}_{2} \mathrm{SO}_{4}(18 \mathrm{M})$ was used in the reaction and that $\mathrm{H}_{2} \mathrm{SO}_{4}-\mathrm{SiO}_{2}$ was effectively sufficient to catalyze the reaction. Also, the same reaction in presence of $0.1 \mathrm{ml}$ of $\mathrm{H}_{2} \mathrm{SO}_{4}(0.1 \mathrm{M})$ was carried out. After $2 \mathrm{~h}$, only $42 \%$ of expected 3 -(2-oxo-2-phenylethyl) isobenzofuran-1(3H)-one (3f) was obtained (entry 3$)$. Then, the effect of temperature on the rate of the reaction was studied for the preparation of 3-(2-oxo-2-phenylethyl) isobenzofuran$1(3 \mathrm{H})$-ones (3f) using $\mathrm{H}_{2} \mathrm{SO}_{4}-\mathrm{SiO}_{2}$ under solvent-free conditions. At $120^{\circ} \mathrm{C}$, the reaction proceeded smoothly and almost complete conversion of product was observed (entry 9). Further increase in temperature to $130^{\circ} \mathrm{C}$ did not increased the rate and the yield of reaction (entry 10). Therefore, we kept the reaction temperature as $120^{\circ} \mathrm{C}$ (giving short reaction time and high yield). Next, the study set out to determine optimal amount of $\mathrm{H}_{2} \mathrm{SO}_{4}-\mathrm{SiO}_{2}$, the reaction was carried out by varying amount of the catalyst (entry 12-13). Maximum yield was obtained with $0.05 \mathrm{~g}$ (entry 9). Further increase in amount of $\mathrm{H}_{2} \mathrm{SO}_{4}-\mathrm{SiO}_{2}$ in the mentioned reaction did not has any significant effect on the product yield (entry 12). No desired product was detected in the absence of the catalyst (entry 14).
Table 1. Screening of the reaction conditions for the synthesis of 3-(2-oxo2-phenylethyl) isobenzofuran-1(3H)-ones (3f).

\begin{tabular}{|c|c|c|c|c|}
\hline Entry & Catalysts & Conditions & $\begin{array}{r}\text { Times } \\
(\mathrm{min})\end{array}$ & $\begin{array}{c}\text { Yield }^{\mathrm{a}} \\
(\%)\end{array}$ \\
\hline 1 & $\mathrm{AcOH}(1 \mathrm{ml})$ & Reflux, $120^{\circ} \mathrm{C}$ & 600 & Trace \\
\hline 2 & $\mathrm{H}_{2} \mathrm{SO}_{4}(18 \mathrm{M}, 0.1 \mathrm{ml})$ & $\begin{array}{c}\text { Solvent- } \\
\text { Free, } 110^{\circ} \mathrm{C}\end{array}$ & 120 & Trace \\
\hline 3 & $\mathrm{H}_{2} \mathrm{SO}_{4}(0.1 \mathrm{M}, 0.1 \mathrm{ml})$ & $\begin{array}{c}\text { Solvent- } \\
\text { Free, } 110^{\circ} \mathrm{C}\end{array}$ & 120 & 42 \\
\hline 4 & $\begin{array}{c}\mathrm{NH}_{4} \mathrm{H}_{2} \mathrm{PO}_{4}-\mathrm{SiO}_{2} \\
(0.04 \mathrm{~g})\end{array}$ & $\begin{array}{c}\text { Solvent- } \\
\text { Free, } 110^{\circ} \mathrm{C}\end{array}$ & 600 & Trace \\
\hline 5 & $\mathrm{AlCl}_{3} \cdot 6 \mathrm{H}_{2} \mathrm{O}(0.05 \mathrm{~g})$ & $\begin{array}{c}\text { Solvent- } \\
\text { Free, } 110^{\circ} \mathrm{C}\end{array}$ & 600 & Trace \\
\hline 6 & $\begin{array}{c}\mathrm{P}_{2} \mathrm{O}_{5}-\mathrm{SiO}_{2}(70 \% \\
w / w, 0.05 \mathrm{~g})\end{array}$ & $\begin{array}{c}\text { Solvent- } \\
\text { Free, } 110^{\circ} \mathrm{C}\end{array}$ & 180 & 52 \\
\hline 7 & $\mathrm{H}_{2} \mathrm{SO}_{4}-\mathrm{SiO}_{2}(0.05 \mathrm{~g})$ & $\begin{array}{c}\text { Solvent- } \\
\text { Free, } 110^{\circ} \mathrm{C}\end{array}$ & 25 & 67 \\
\hline 8 & $\begin{array}{c}\text { Poly [AMPS-co-AA] } \\
(0.1 \mathrm{~g})\end{array}$ & $\begin{array}{c}\text { Solvent- } \\
\text { Free, } 110^{\circ} \mathrm{C}\end{array}$ & 360 & 62 \\
\hline 9 & $\mathrm{H}_{2} \mathrm{SO}_{4}-\mathrm{SiO}_{2}(0.05 \mathrm{~g})$ & $\begin{array}{c}\text { Solvent- } \\
\text { Free, } 120^{\circ} \mathrm{C}\end{array}$ & 20 & 82 \\
\hline 10 & $\mathrm{H}_{2} \mathrm{SO}_{4}-\mathrm{SiO}_{2}(0.05 \mathrm{~g})$ & $\begin{array}{c}\text { Solvent- } \\
\text { Free, } 130^{\circ} \mathrm{C}\end{array}$ & 20 & 72 \\
\hline 11 & $\mathrm{H}_{2} \mathrm{SO}_{4}-\mathrm{SiO}_{2}(0.05 \mathrm{~g})$ & $\begin{array}{c}\text { Solvent- } \\
\text { Free, } 100^{\circ} \mathrm{C}\end{array}$ & 25 & 54 \\
\hline 12 & $\mathrm{H}_{2} \mathrm{SO}_{4}-\mathrm{SiO}_{2}(0.07 \mathrm{~g})$ & $\begin{array}{c}\text { Solvent- } \\
\text { Free, } 120^{\circ} \mathrm{C}\end{array}$ & 20 & 66 \\
\hline 13 & $\mathrm{H}_{2} \mathrm{SO}_{4}-\mathrm{SiO}_{2}(0.03 \mathrm{~g})$ & $\begin{array}{c}\text { Solvent- } \\
\text { Free, } 120^{\circ} \mathrm{C}\end{array}$ & 25 & 52 \\
\hline 14 & - & $\begin{array}{c}\text { Solvent- } \\
\text { Free, } 120^{\circ} \mathrm{C}\end{array}$ & 120 & $-\mathrm{b}$ \\
\hline
\end{tabular}

${ }^{a}$ Isolated yields. ${ }^{b}$ No Reaction.

To further explore the scope of this protocol, we decided to investigate the condensation reaction of phthalaldehydic acid (2-carboxy benzaldehyde) with another aryl ketones or 1,3-dicarbonyl compounds (Table 2). (3a-k)

Proposed Mechanism for the Synthesis of Isobenzofuran-1(3H)-one A per the formation of isobenzofuran-1(3H)-one (3a-k) in the presence of $\mathrm{H}_{2} \mathrm{SO}_{4}-\mathrm{SiO}_{2}$ is proposed in Scheme 2. The reaction proceeds in two steps; an aldol condensation and the subsequent cyclization (lactonization).

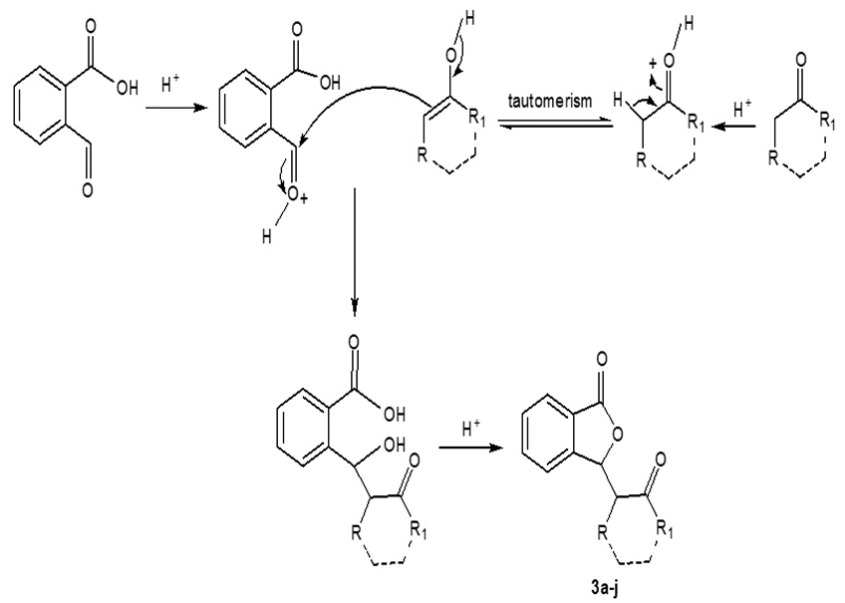

Scheme 2. Mechanism for the formation of isobenzofuran-1(3H)-one (3ak) in the presence of $\mathrm{H}_{2} \mathrm{SO}_{4}-\mathrm{SiO}_{2}$

Studying Reusability of the Catalyst $\mathrm{H}_{2} \mathrm{SO}_{4}-\mathrm{SiO}_{2}$

The recycling and reuse of $\mathrm{H}_{2} \mathrm{SO}_{4}-\mathrm{SiO}_{2}$ was investigated for the synthesis of 3-(2-oxo-2-phenylethyl) isobenzofuran-1 $(3 H)$-ones (3f) in three consecutive runs. The results summarized in Table 3 indicate a gradual decrease in the isolated yields from $82 \%$ to $78 \%$. 
Table 2. The heterogeneous synthesis of isobenzofuran-1(3H)-ones using $\mathrm{H}_{2} \mathrm{SO}_{4}-\mathrm{SiO}_{2}$

\begin{tabular}{|c|c|c|c|c|c|c|}
\hline \multirow{2}{*}{ Enty } & \multirow{2}{*}{$\begin{array}{c}\text { Ketones } \\
2\end{array}$} & \multirow[t]{2}{*}{ Isobenzofuran-1(3H)-ones 3} & \multirow{2}{*}{ Time (min) } & \multirow{2}{*}{ Yield $(\%)^{a}$} & \multicolumn{2}{|c|}{$\mathrm{Mp}\left({ }^{0} \mathrm{C}\right)$} \\
\hline & & & & & Found & Reported \\
\hline $3 \mathbf{a}$ & & & 40 & 80 & 77 & $78^{26}$ \\
\hline $3 \mathbf{b}$ & & & 60 & 72 & 103 & $105^{26}$ \\
\hline $3 \mathbf{c}$ & & & 60 & 70 & $164-166$ & $165-167^{26}$ \\
\hline 3d & & & 25 & 74 & $212-214$ & $208-210^{16}$ \\
\hline $3 \mathbf{e}$ & & & 60 & 76 & oil & $\mathrm{Oil}^{24}$ \\
\hline $3 f$ & & & 20 & 82 & $144-145$ & $145^{26}$ \\
\hline $3 g$ & & & 40 & 88 & $212-214$ & $210^{26}$ \\
\hline $3 \mathbf{h}$ & & & 30 & 86 & $142-144$ & $146^{26}$ \\
\hline $3 \mathbf{i}$ & & & 20 & 82 & $217-219$ & $219^{26}$ \\
\hline $3 \mathbf{j}$ & & & 30 & 80 & 148 & $149^{26}$ \\
\hline $3 k$ & & & 40 & 76 & $212-214$ & $216-217^{16}$ \\
\hline
\end{tabular}

${ }^{a}$ The yields refer to the isolated pure products which were characterized from their spectral data and were compared with authentic sample. 
Table 3. Reuse of the $\mathrm{H}_{2} \mathrm{SO}_{4}-\mathrm{SiO}_{2}$ for synthesis of 3-(2-oxo-2-phenylethyl) isobenzofuran-1 $(3 H)$-ones $(\mathbf{3 f})$.

\begin{tabular}{|c|c|c|}
\hline Entry & Times (min) & Yield $^{\text {a }} \mathbf{( \% )}$ \\
\hline 1 & 20 & 82 \\
\hline 2 & 20 & 80 \\
\hline 3 & 30 & 78 \\
\hline
\end{tabular}

${ }^{\mathrm{a}}$ Isolated yields.

\section{Studying Third-Order Nonlinear Optical Properties}

Materials with third-order optical nonlinearities have been investigated widely for their applications in opto-electronic and all-optical devices such as eye and sensor protection, optical phase conjugation, high-speed all optical switches, optical bistability, optical limiting devices, optical modulators and so on ${ }^{47-49}$. Organic materials exhibiting strong nonlinear optical properties have attracted considerable interest in recent years because of their possible applications in nonlinear optical devices ${ }^{50-51}$. Conjugated polymers are a promising class of third-order nonlinear materials because of their potentially large third-order susceptibilities associated with fast response time in addition to their variety and processability ${ }^{47}$.

One of the interesting properties of organic molecules is their nonlinear optical behavior in laser irradiations. The main origin of these treatments is the $\pi$ electrons which gives rise to marked optical nonlinearities. The value for the nonlinear polarization of the $\pi$-electrons is large, even for radiation frequencies far removed from the electronic resonances involved (in which a carbon molecule absorbs an incident photon). The absorption spectrum of such material depends on a large extent on the degree of electron-conjugation present within the $\pi$-orbital. In particular, $\lambda_{\max } \propto L_{d}$, where $L_{d}$ is the conjugation length ${ }^{47,52}$. Also, the conjugation length is proportional to the real part of third order susceptibility. Nonlinear refraction index $n_{2}$ is the best measurable coefficient to evaluate third order nonlinearity ${ }^{53}$

The best method to measuring third order nonlinear refractive index is closed-aperture z-scan method ${ }^{54}$. In this technique a laser Gaussian beam passing through a lens and a thin sample containing the subject material scans a distance surrounding the focal point of the beam. The transmitted power through a finite aperture in far field leads to calculate $n_{2}$.

For determining the nonlinear refractive index, the closed-aperture z-scan setup shown in Fig.1 was employed initially. The light source was a CW HeNe laser beam $\lambda=632.8 \mathrm{~nm}$, with $48 \mathrm{~mW}$ maximum power, $30 \mu \mathrm{m}$ beam waist radius, and the focal length of convergence lens was $8 \mathrm{~cm}$. the irradiation intensity at the beam waist $\operatorname{was}_{I_{0}}=3340 \mathrm{~W} / \mathrm{g}_{2} .0 .1 \mathrm{M}$ concentrations of both the components in DMSO were prepared and poured into $1 \mathrm{~mm}$ length quartz cells. The normalized transmittances of the samples have been shown in Figs. 2 and 3 . Using the numerical curve fitting, the values of nonlinear refraction indexes for 3-(2-hydroxy-4,4-dimethyl-6-oxo-cyclohexen-1-yl-3H-isobenzofuran1 -one (3d) and 3-(2-oxo-2-phenylethyl) isobenzofuran-1(3H)-ones (3f) were obtained $-1.64 \times 10^{-8} \mathrm{~cm}^{2} / W$ and $-2.34 \times 10^{-8} \mathrm{~cm}^{2} / W$, respectively. This could interpreted simplify using molecular structures where the electron paths have been drown schematically. As shown in figures, the conjugation length in $3 \mathrm{~d}$ is longer than for 3f. Considering these magnitudes of nonlinear refractive index, these components have good potential in nonlinear optical devices.

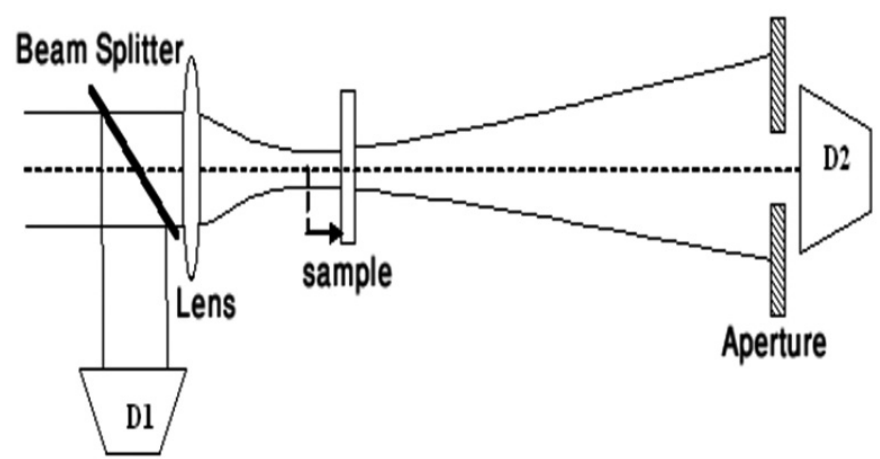

Fig. 2. Schematic description of close aperture z-scan setup.

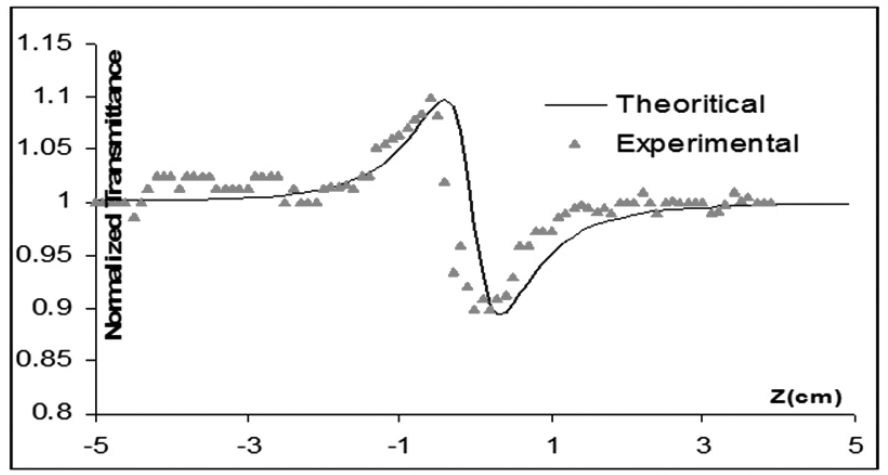

Fig. 3. Normalized transmittance of close aperture z-scan for 3-(2-oxo-2phenylethyl) isobenzofuran-1(3H)-ones (3f)

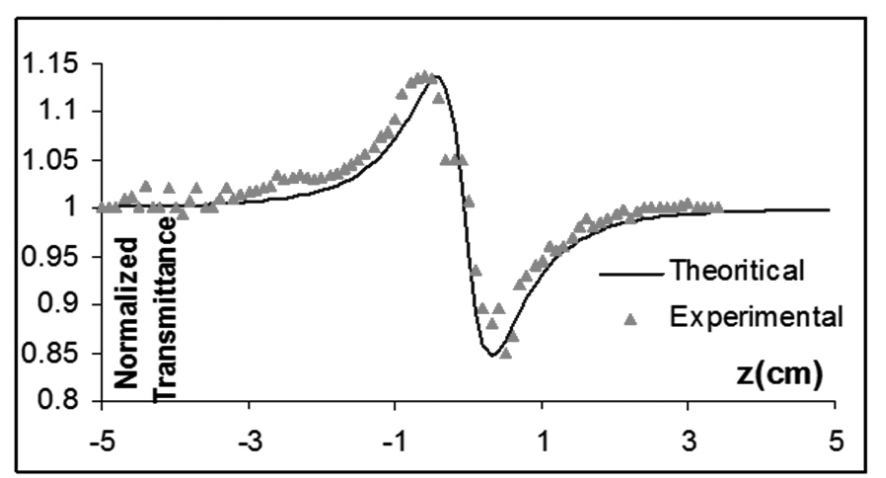

Fig. 4. Normalized transmittance of close aperture z-scan for 3-(2-hydroxy4,4-dimethyl-6-oxo-cyclohexen-1-yl-3H-isobenzofuran-1-one (3d)

\section{CONCLUSION}

In conclusion, this paper describes an efficient, heterogeneous, simple and safe procedure for the preparation of the isobenzofuran-1(3H)-ones derivatives. Considerable optical nonlinearity due to high polarization of the $\pi$-electrons and also thermal effect is observed in the mentioned components. It was found that the components could be good candidates for electro-optical devices and optical modulators. Also, dependency of nonlinear optical indexes to the conjugation length of the components has been studied.

\section{EXPERIMENTAL}

Commercially available materials were purchased from Merck, Fluka and Aldrich, and were used without additional purification. $\mathrm{H}_{2} \mathrm{SO}_{4}-\mathrm{SiO}_{2}$ was prepared according to literature [42]. IR spectra were recorded on a Shimadzu 435-U-04 spectrophotometer ( $\mathrm{KBr}$ pellets). ${ }^{1} \mathrm{H}$ and ${ }^{13} \mathrm{C}$ NMR spectra were obtained using Bruker DRX-300 Advance spectrometer in DMSO- $\mathrm{d}_{6}$ or $\mathrm{CDCl}_{3}$ using TMS as an internal reference. Melting points were determined in open capillary tubes in a Stuart BI Branstead Electrothermal Cat No: IA9200 apparatus and uncorrected.

General procedure for the synthesis of isobenzofuran-1(3H)-ones derivatives

To a mixture of aryl ketones or 1,3-dicarbonyl compounds (1.2 mmol) and phthalaldehydic acid (2-carboxy benzaldehyde) (1 mmol), $\mathrm{H}_{2} \mathrm{SO}_{4}-\mathrm{SiO}_{2}$ $(0.05 \mathrm{~g})$ was added and the mixture was heated on an oil bath at $120^{\circ} \mathrm{C}$ for the reasonable time (Table 2). After completion of the reaction (monitored by TLC, hexane:ethyl acetate, 8:2), the reaction mixture diluted with EtOH $(96 \%, 3 \mathrm{ml})$ and stirred for $5 \mathrm{~min}$ in $120^{\circ} \mathrm{C}$. The resulting crude product was poured into crushed ice and the solid product, which separated was filtered and recrystallized from ethanol to get pure products $(\mathbf{3 a}-\mathbf{k})$.

Selected spectral data

3-(1,3-Dihydro-3-oxo-1-isobenzofuranyl)-2,4-pentanedione (3b)

FT-IR (KBr, $\left.v, \mathrm{~cm}^{-1}\right):$ 3002, 2930, 1770, 1710, 1690 1450, 1400, 1280, 1240, 1080,720, 680. ${ }^{1} \mathrm{H}$ NMR (CDCl $\left., 300 \mathrm{MHz}, \delta, \mathrm{ppm}\right): 2.21$ (s, 3H), 2.34 $(\mathrm{s}, 3 \mathrm{H}), 4.04(\mathrm{~d}, 1 \mathrm{H}), 6.13(\mathrm{~d}, 1 \mathrm{H}), 7.41-7.82(\mathrm{~m}, 4 \mathrm{H}) .{ }^{13} \mathrm{C} \mathrm{NMR}\left(\mathrm{CDCl}_{3}, 75\right.$ MHz, $\delta$, ppm): $29.91,30.43,72.00,78.54,123.34,125.68,126.09,130.21$, 
134.62, 146.97, 169.54, 198.91, 200.92. 3-(2-Hydroxy-4,4-dimethyl-6-oxo-cyclohexen-1-yl-3H-isobenzofuran-1one (3d)

FT-IR (KBr, $\left.v, \mathrm{~cm}^{-1}\right)$ : 3489, 2982, 1770, 1663, 1575, 1398, 1323, 1292, 1200, 1070, 770, 680. ${ }^{1} \mathrm{H}$ NMR ( $\mathrm{CDCl}_{3}, 300 \mathrm{MHz}, \delta$, ppm): 0.99 (s, 6H), 2.42 (s, 4H), $6.74(\mathrm{~s}, 1 \mathrm{H}), 7.09-7.86(\mathrm{~m}, 4 \mathrm{H}) ;{ }^{13} \mathrm{C} \mathrm{NMR}\left(\mathrm{CDCl}_{3}, 75 \mathrm{MHz}, \delta, \mathrm{ppm}\right)$ : $28.98,32.87,46.87,73.48,109.12,122.01,124.78,126.89,127.09,132.12$, $151.42,169.89,182.54$.

\section{3-(2-oxo-2-phenylethyl) isobenzofuran-1(3H)-one $(3 f)$}

FT-IR (KBr, $\left.v, \mathrm{~cm}^{-1}\right): 3020,2980,1700,1660,16001460,1400,1280$, 1200, 1080,760, 680. ${ }^{1} \mathrm{H}$ NMR ( $\mathrm{CDCl}_{3}, 300 \mathrm{MHz}, \delta$, ppm): 3.41 (d, $\left.1 \mathrm{H}\right), 3.86$ $(\mathrm{d}, 1 \mathrm{H}), 6.12(\mathrm{t}, 1 \mathrm{H}), 7.62-8.04(\mathrm{~m}, 9 \mathrm{H}) ;{ }^{13} \mathrm{C} \mathrm{NMR}\left(\mathrm{CDCl}_{3}, 75 \mathrm{MHz}, \delta, \mathrm{ppm}\right)$ : $43.65,76.45,123.98,124.54,125.09,127.12,128.46,129.12,129.86,132.43$, $134.68,145.79,170.64,198.92$.

3-(2-oxo-2-4-methylphenylethyl) isobenzofuran-1(3H)-one (3j)

FT-IR (KBr, $\left.v, \mathrm{~cm}^{-1}\right): 3010,2960,1750,1670,1610$ 1470, 1410, 1290, 1200, 1090,760, 680. 'H NMR ( $\left.\mathrm{CDCl}_{3}, 300 \mathrm{MHz}, \delta, \mathrm{ppm}\right): 2.45$ (s, 3H), 3.43(d, 1H), $3.86(\mathrm{~d}, 1 \mathrm{H}), 6.32(\mathrm{t}, 1 \mathrm{H}), 7.56-7.98(\mathrm{~m}, 8 \mathrm{H}) ;{ }^{13} \mathrm{C} \mathrm{NMR}\left(\mathrm{CDCl}_{3}\right.$, $75 \mathrm{MHz}, \delta$, ppm): 28.24, 43.05, 77.25, 121.94, 123.14, 124.09, 125.12, 127.26, $128.72,129.96,133.43,135.14,144.67,171.94,196.76$

\section{ACKNOWLEDGEMENTS}

The authors are thankful to research council of Hakim Sabzevari University for financial support.

\section{REFERENCES}

1. K. Yoganathan, C. Rossant, S. Ng, Y. Huang, M. S. Butler, A.D. Buss, J. Nat. Prod. 66, 1116, (2003).

2. F. O. Shode, A. S. Mahomed, C. B. Rogers, Phytochemistry 61, 955, (2002).

3. H. Inouye, T. Okuda, Y. Hirata, N. Nagakura, M. Yoshizaki, Chem. Pharm. Bull. Jpn. 15, 786, (1967).

4. Palermo, J. A. Brasco, M. V. R. Spagnuolo, C. Seldes, A. M. J. Org. Chem. 65, 4482, (2000).

5. A. Arnone, G. Assante, G. Nasini, O. V. DePava, Phytochemistry 29, 613, (1990).

6. J. Fuska, D. Uhrin, B. Proksa, Z. Voticky, J. Ruppeldt, J. Antibiot. 39, 1605, (1986).

7. C. Puder, A. Zeeck, W. Beil, J. Antibiot. 53, 329, (2000).

8. G. Blasko, D. J. Gula, M. Shamma, J. Nat. Prod. 45, 105, (1982).

9. G. Strobel, E. Ford, J. Worapong, J. K. Harper, A. M. Arif, D. M. Grant, P. C. W. Fung, R. M. W. Chau, Phytochemistry 60, 179, (2002).

10. A. Arnone, G. Assante, G. Nasini, S. Strada, A. Vercesi, J. Nat. Prod. 65, 48, (2002).

11. H. Yang, G. Y. Hu, J. Chen, Y. Wang, Z. H. Wang, Bioorg. Med. Chem Lett. 17, 5210, (2007).

12. S. Mor, S. N. Dhavan, M. Kapoor, D. Kumar, Tetrahedron 63, 594, (2007).

13. M. V. Paradkar, S. Y. Gadre, T. A. Pujari, P. P. Khandekar, V. B. Kumbhar, Synth. Commun. 35, 471, (2005).

14. E. W. Bousquet, M. D. Moran, J. Harmon, A. L. Johnson, J. C. Summers, J. Org. Chem. 40, 2208, (1975).

15. P. Pahari, B. Senapati, D. Mal, Tetrahedron Lett. 45, 5109, (2004).

16. D. Mal, P. Pahari, S. C. De, Tetrahedron 63, 11781, (2007)

17. D. C. G. A. Pinto, A. M. S. Silva, J. A. S. Jcavaleiro, J. Elguero, Eur. J. Org. Chem. 3, 747, (2003).

18. E. W. Bousquet, M. D. Moran, J. Harmon, A. L. Johnson, J. C. Summers, J. Org. Chem. 40, 2208, (1975).

19. S. L. Shapiro, K. Geiger, L. Freedman, J. Org. Chem. 26, 3580, (1961).

20. S. L. Shapiro, K. Geiger, L. Freedman, J. Org. Chem. 25, 1860, (1960).

21. R. L. Shriner, L. S. Keyser, J. Org. Chem. 5, 200, (1940)

22. M. V. Paradkar, S. Y. Gadre, T. A. Pujari, P. P. Khandekar, V. B. Kumbhar, Synth. Commun. 35, 471, (2005).

23. R. Rendy, Y. Zhang, A. McElrea, A. Gomez, D. A. Klumpp, J. Org. Chem. 69, 2340, (2004).

24. S. M. Landge, M. Berryman, B. Torok, Tetrahedron Lett. 49, 4505, (2008).

25. J. Safari, H. Naeimi, A. K. Khakpour, R. Sharifi Jondani, S. Dehgan Khalili, J. Mol. Catal. A: Chem. 270, 236, (2007).

26. J. N. Sangshetti, S. A. M. K. Ansar, D. B. Shinde, Chin. Chem. Lett. 22, $163,(2011)$.

27. A. Emrani, A. Davoodnia, N. Tavakoli-Hoseini, Bull. Korean Chem. Soc. 32, 2385, (2011).
28. S. A. Pourmousavi, Z. Zinati, Turk. J. Chem. 33, 385, (2009).

29. G. Thirunarayan, V. Renuka. J. Chil. Chem. Soc. 59, 2574, (2014).

30. S. Tekale, S. Kuthale, R. Pawar, J. Chil. Chem. Soc. 58, 1619, (2013).

31. A. Davoodnia, A. Khojastehnezhad, J. Chil. Chem. Soc. 57, 1385, (2012).

32. M. A. Zolfigol, P. Salehi, M. Shiri, T. Fall Rastegar, A. Ghaderi, J. Iran. Chem. Soc. 5, 490, (2008)

33. R. S. Vrama, Green Chem. 1, 43, (1999).

34. F. Khamooshi, B. Kekhaiyejhaleh, J. Chil. Chem. Soc. 58, 1691, (2013)

35. E. Rafiee, F. Rahimi, J. Chil. Chem. Soc. 58, 1926, (2013).

36. R. Tayebee, B. Maleki, M. Gadamghaei, Chin. J. Catal. 3, 659, (2012).

37. H. Veisi, B. Maleki, F. Hosseini Eshbala, H. Veisi, R. Masti, S. Sedigh Ashrafi, M. Baghayeri, RSC Adv. 4, 30683 (2014).

38. B. Maleki, S. Sedigh Ashrafi, RSC Adv. 4, 42873 (2014).

39. B. Maleki, R. Tayebee, Z. Sepehr, M. Kermanian, Acta Chim. Slov. 59, 814 (2012).

40. B. Maleki, M. Mohammadi, H. Keshvari, R. Sandaroos, B. Maleki, H. Rouhi, H. A. Moradi, Z. Sepehr, S. Damavandi, Appl. Cat. A Gen. 329330, 73, (2012)

41. B. Maleki, S. Barzegar, Z. Sepehr, M. Kermanian, R. Tayebee, J. Iran. Chem. Soc. 9, 757, (2012).

42. B. Maleki, H. Salehabadi, M. Khodaverdian Moghaddam, Acta Chim. Slov. 57, 741, (2010).

43. B. Maleki, S. Hemmati, A. Sedrpoushan, S. Sedigh Ashrafi, H. Veisi, RSC Adv. 4, 40505 (2014)

44. B. Maleki, H. Veisi, Bull. Korean Chem. Soc. 32, 4366, (2011).

45. B. Maleki, S. Sedigh Ashrafi, R. Tayebee, RSC Adv. 4, 41521, (2014).

46. B. Maleki, F. Taimazi, Org. Prep. Proced. Int. 46, 252, (2014).

47. P.N. Prasad, D.J. Williams, Introduction to Nonlinear Optical Effects in Molecules and Polymers, John Wiley \& Sons Inc., New York, (1991).

48. S. L. Guo, T. P. Li, T. B. Wang, Z. S. Liu, T. D. Cao, Optical Mater. 29 , 494, (2007)

49. L. W. Tutt, A. Kost, Nature 356, 224, (1992).

50. D. Udayakumar, A. J. Kiran, A. V. Adhikari, K. Chandrasekharan, G. Umesh, H. D. Shashikala, Chem. Physic. 331, 125, (2006).

51. J. Zyss, Molecular Nonlinear Optics Materials, Physics, and Devices, Academic Press, London, 1994.

52. M. H. Majles Ara, E. Koushki, S. H. Mousavi, S. Salmani, M. Rafizadeh, A. Gharibi, Chem. Physic. 109, 320, (2008).

53. M. Sheik-bahae, A. A. Said, T. H. Wei, D. J. Hagan, E. W. Van Stryland, IEEE J. Quantum Electron. 26, 760, (1990).

54. E. Koushki, A. Farzaneh, Optics Commun. 285, 1390, (2012). 